\title{
Foraging and habitat specialization by female leopards (Panthera pardus) in the Waterberg Mountains of South Africa
}

\author{
Ross T. Pitman ${ }^{1 *}$, Petrus J. Kilian ${ }^{2}$, Paul M. Ramsay ${ }^{1}$ \& Lourens H. Swanepoel ${ }^{3}$ \\ ${ }^{1}$ Marine Biology and Ecology Research Centre, School of Biomedical and Biological Sciences, \\ Plymouth University, Plymouth, PL4 8AA, U.K. \\ ${ }^{2}$ Khamab Kalahari Reserve, Bray, North West Province, South Africa \\ ${ }^{3}$ Centre for Wildlife Management, University of Pretoria, Pretoria, 0002 South Africa
}

Received 19 March 2013. Accepted 18 July 2013

\begin{abstract}
Carnivores that persist outside of protected areas are often deemed to have highly adaptable and generalist foraging strategies. Using data from three GPS-collared female leopards (Panthera pardus) and over an eight-month period, we attempted to establish whether leopards in a mountainous landscape display preferential behaviour (i.e. specialist) or not (i.e. generalist). We investigated whether female leopards used habitats in accordance with availability for both hunting and regular activities, and whether female leopards demonstrated preference for a particular prey species. Finally, we assessed tree caching behaviour and discuss leopard spatial dynamics in the context of superior competitors, such as lions (Panthera leo). Female leopards demonstrated selection for certain prey species. Mixed closed woodland (greatest vegetation density; lowest prey density) and tall open woodland (greatest vegetation biomass; high prey density) were preferred over other habitats. Female leopards on Welgevonden cached significantly larger prey species in trees. Our results suggest that female leopards in this landscape are selecting habitats - enabling the exploitation of certain ecological features - that balance energy expenditure against the likelihood of capturing prey in an attempt to maximize efficiency, whilst reducing inter-specific competition. We suggest that female leopards are limited in their foraging ability as a result of interference competition by superior species like lions, which in turn, affects their choice of prey. These findings highlight the potential importance of numerous ecological, spatio-temporal, and anthropogenic factors that influence leopard behaviour, and therefore have significant implications for leopard persistence and conservation.
\end{abstract}

Keywords: predation, kill site, carnivore, GPS cluster analysis, preference, optimal foraging.

\section{INTRODUCTION}

Due to their dietary plasticity and ecological adaptability, the leopard, Panthera pardus, is the most successful and wide-ranging large felid in Africa (Ray et al. 2005). Leopards often inhabit areas greatly modified by people or within close proximity to human settlements. Consequently, leopards are frequently regarded as opportunistic generalists, exhibiting wide habitat tolerances and resilience to anthropogenic threats (Hayward et al. 2006). However, research is beginning to reveal their specialized foraging behaviour (Balme et al. 2007; Hayward et al. 2007).

The positive relationship between prey biomass and leopard density is well established (Marker \& Dickman 2005). However, leopards prefer prey species weighing an average of $23 \mathrm{~kg}$ (Hayward

\footnotetext{
*To whom correspondence should be addressed.
}

E-mail: rosstyzackpitman@me.com et al. 2006). Subsequent predictions of leopard density based on preferred prey biomass (Hayward et al. 2007) suggest that leopard populations are not just dependent on prey biomass alone, but rather, prey biomass within a suitable weight category.

Many factors can influence leopard diet (Steinmetz et al.2013). For example, leopard prey density and composition can be affected by other predators, leading to dietary overlap resulting in increased competition for resources (Harihar et al. 2011). Additionally, anthropogenic pressure can alter food webs through activities such as overhunting of prey populations which can either drive leopards towards local extinction or force them to consume smaller prey (Henschel et al. 2011). Another factor affecting leopard diet is vegetation cover. Research has demonstrated that leopards have a greater probability of capturing prey when hunting occurs 
in habitats with intermediate vegetation cover, even though these habitats contain lower prey densities than that of surrounding areas (Balme et al. 2007). These findings suggest that the likelihood of capturing prey and factors affecting this probability, like vegetation cover, are important determinants of leopard density and persistence. As a result of these recent studies, important questions are raised concerning leopard resilience in human-dominated landscapes and how adaptable these populations are. These issues are all the more pressing as the threats towards leopards are escalating due to extensive habitat loss (Ray et al. 2005), human-leopard conflict (Athreya et al. 2011), overhunting of leopards (Packer et al. 2011) and changes in prey composition due to human exploitation of leopard prey populations (Henschel et al. 2011).

The majority of scientific publications in southern Africa describing specialization by leopards have been conducted in open savanna systems (Stander et al. 1997; Hayward et al. 2006; Balme et al. 2007). Limited data exist regarding the preferences and ecological requirements of leopards in mountainous environments. This paper aims to answer one basic question: to what degree do leopards in a mountainous landscape show foraging and habitat specialization? We aim to 1) assess whether leopards prefer one species to another, 2) determine whether leopards use available habitats equally, and 3) assess whether predation occurs equally within available habitats, by monitoring three GPS-collared leopards over an eight-month period.

\section{METHODS}

\section{Study area}

The study was conducted in Welgevonden Private Game Reserve $\left(24^{\circ} 10^{\prime}-24^{\circ} 25^{\prime} \mathrm{S}\right.$ and $27^{\circ} 45^{\prime}-$ $27^{\circ} 56^{\prime} \mathrm{E}$; hereafter referred to as Welgevonden) situated on the Waterberg Plateau, Limpopo Province, South Africa, from August 2010 to March 2011. Welgevonden is characterized by mountains and flat hilltop plateaus dissected by steep valleys and ravines, and contains both natural rivers, artificial dams and permanent waterholes that sustain large populations of wildlife annually (Parker 2004). Fifty-two large mammal species are documented to occur on the reserve, including three primates, 17 ungulates and 19 carnivores.

The soil is sandy, acidic and nutrient-poor, giving rise to low-quality sourbush (Killian 2003). The vegetation is classified as Waterberg Mountain Bushveld, dominated by wild seringa (Burkea africana), Transvaal beech (Faurea saligna), Transvaal milkplum (Englerophytum magalismontanum) and horn pod (Diplorhynchus condylocarpon) (Mucina \& Rutherford 2006). Welgevonden lies in a summer rainfall region with an annual average precipitation of $613 \mathrm{~mm}$ and average temperature of $18.8^{\circ} \mathrm{C}$ (Institute of Soil, Climate and Water AgroMed section 2008). The dry season ranges from April to September and the wet season, from October to March.

Six vegetation types were classified by Parker (2004): grasslands (GR), open rocky woodland (ORW), mixed closed woodland dominated by $B$. africana with $D$. condylocarpon subcommunity (MCW), mixed woodland dominated by $B$. africana with $E$. magalismontanum subcommunity (MW), open woodland dominated by $B$. africana with Terminalia sericea subcommunity (OW), and tall open woodland dominated by $B$. africana with F. saligna subcommunity (TOW). A digitized vegetation map in ArcGIS v.9.2 (ESRI, Redlands, CA, U.S.A.) covering the entire reserve was used for the analysis (Fig. 1).

\section{Capture and immobilization}

The capture and collaring of leopards was undertaken as part of a larger study (Pitman et al. 2012). Leopards were captured using soft-hold foot snares (Frank et al. 2003), and immobilized using 4-5 mg/kg teletamine-zolazepam (Zoletil 100, Virbac RSA, Halfway House, South Africa). Three female leopards were fitted with remote drop-off global positioning systems (GPS) collars (Followit Tellus, Lindesberg, Sweden) and released within $3 \mathrm{~km}$ of the capture site after full recovery from the anaesthetic drug. GPS collars were remotely released after completion of the study. This study was approved by the University of Pretoria Animal Use and Care Committee ethics clearance protocol A022-06 with all its amendments and Limpopo standing permit (no. S13631) for scientific research.

\section{Foraging activity}

One hundred and twenty nine kills by three female leopards were located using contextual GPS cluster analysis (Tambling et al. 2010; Pitman et al. 2012). Each GPS collar was programmed to record 11 locations per day, totalling 6668 GPS locations for the study period. Leopard GPS clusters are locations in time and space, determined by a set of decision rules: 1) consecu- 


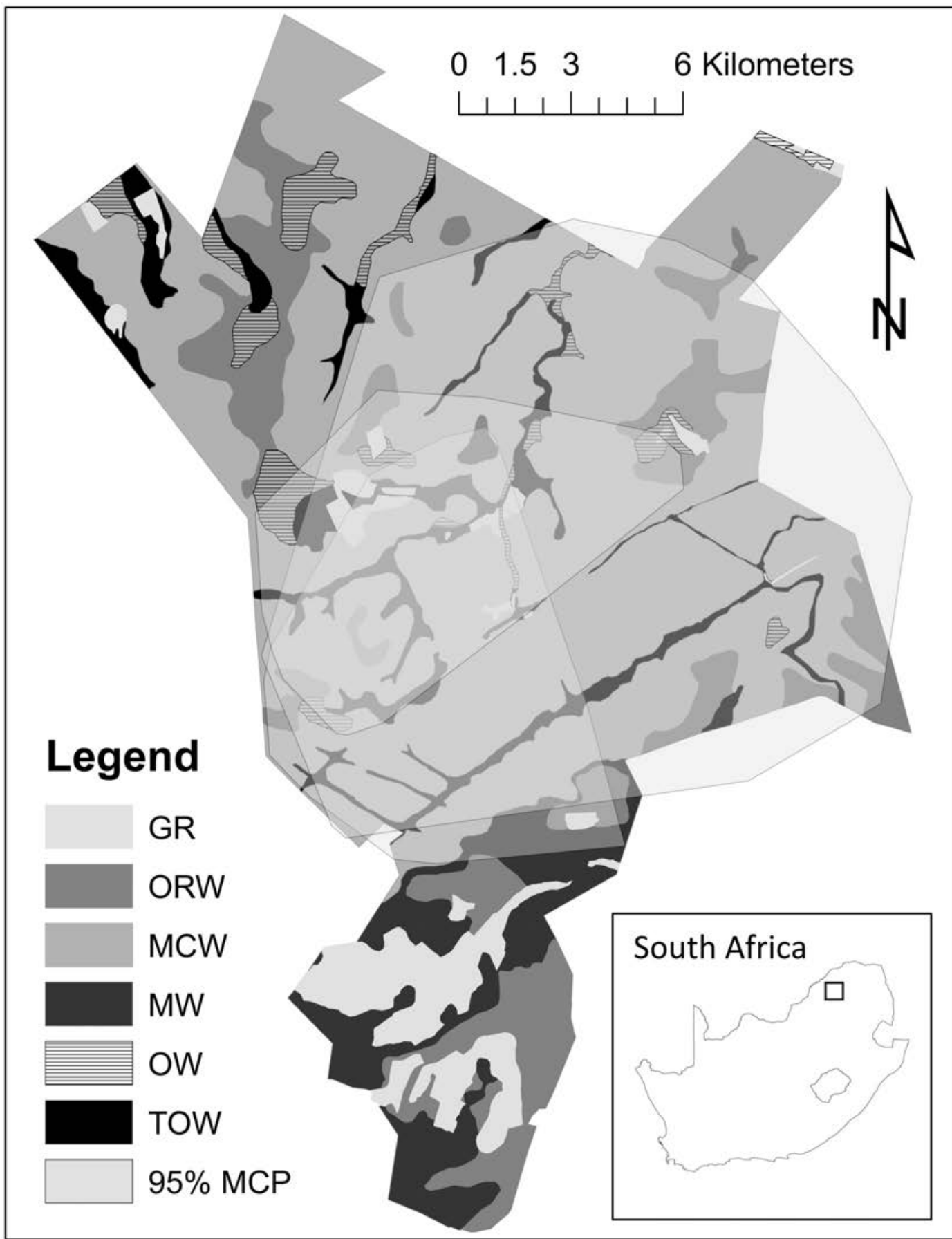

Fig. 1. Map of Welgevonden Private Game Reserve, Limpopo Province, South Africa, showing home ranges of three female leopards (95\% minimum convex polygon; MCP) and six major vegetation types: $\mathrm{GR}=$ grasslands, ORW = open rocky woodland, $\mathrm{MCW}=$ mixed closed woodland dominated by $B$. africana with $D$. condylocarpon subcommunity, $\mathrm{MW}=$ mixed woodland dominated by $B$. africana with $E$. magalismontanum subcommunity, $\mathrm{OW}=$ open woodland dominated by $B$. africana with Terminalia sericea subcommunity, and TOW = tall open woodland dominated by $B$. africana with F. saligna subcommunity. Inset: square indicates the reserve's location within South Africa. 
tive GPS locations within 50 m of each other were merged into one cluster, and 2) clusters within $100 \mathrm{~m}$ and $8 \mathrm{~h}$ (closest point to closest point) of other clusters were merged (refer to Pitman et al. 2012 for further details regarding these methods). These clusters $(n=356)$ were investigated in the field for kills. Leopard kill remains were identified macroscopically (e.g. horns, skull) or microscopically (cuticular hair scale patterns and crosssections) using published references (Dreyer 1966; Keogh 19791983; Buys \& Keogh 1984; Douglas 1989), and a reference collection housed at the Centre of Wildlife Management, University of Pretoria, South Africa. We measured the time predation occurred (diurnal $=6$ am-4 pm; crepuscular $=4$ am or $6 \mathrm{pm}$; nocturnal $=8 \mathrm{pm}-2 \mathrm{am})$, taken at the start of a cluster and whether or not the carcass was cached. Vegetation density (woody stems $\left./ \mathrm{km}^{2}\right)$ and vegetation biomass $\left(\mathrm{kg} / \mathrm{km}^{2}\right)$ for each vegetation type on Welgevonden were obtained from (Parker 2004; Table 2). Leopard activity patterns were measured using Hawth's Analysis Tools v.3.27 (Beyer 2004) by averaging the distance moved between each consecutive GPS location and compared over a $24 \mathrm{~h}$ cycle.

\section{Prey demographics}

Twelve years of aerial count data (one count per year) were collated to create digital habitat utilization maps for each prey species on Welgevonden. Aerial counts were conducted at the end of the dry season, when wildlife is most easily detected. Welgevonden was systematically surveyed using a helicopter by flying $400 \mathrm{~m}$ transects in an easterly/westerly direction over a four-day period to ensure equal detection of prey species in each vegetation type.

Prey abundance was calculated by averaging the three most recent aerial counts (2008-2010) for each species. Aerial census techniques are biased against smaller, cryptic animals, and therefore correction factors (see Table 1) were applied to account for these species (Owen-Smith \& Mills 2008). There was severe undercounting of klipspringer (Oreotragus oreotragus) and common duiker (Sylvicapra grimmia) as a result of the census technique. Therefore, their abundance estimates were calculated by multiplying the amount of suitable habitat available to each species (klipspringer $=318 / \mathrm{km}^{2}$, entire reserve minus GR; common duiker $=340 / \mathrm{km}^{2}$, entire reserve) by their average recorded densities (klipspringer $=0.3 / \mathrm{km}^{2}$ and common duiker $=0.3 \mathrm{~km}^{2}$ ) obtained from field observations (Stuart \& Stuart 2000; Skinner \& Chimimba 2005).

Prey density estimates (animals $/ \mathrm{km}^{2}$ ) were generated for each vegetation type by dividing the average number of individuals (2008-2010) in each vegetation type by the available area within each vegetation type covering the entire reserve. Biomass estimates $\left(\mathrm{kg} / \mathrm{km}^{2}\right)$ for each species in each vegetation type were calculated by multiplying density estimates by prey weights (Table 2). Average prey weights were determined by multiplying mean adult female weights by 0.75 to account for an assumed proportion of juveniles within the prey population (Stuart \& Stuart 2000; Skinner \& Chimimba 2005; Hayward et al. 2006). We did not evaluate seasonal variation of prey distribution. The short duration of the study (i.e. throughout the wet season), year-round availability of water, supplementary feeding of herbivores, and the small size of Welgevonden suggest that species migrations within the reserve are minimal (Parker 2004).

\section{Statistical methods}

We used G-tests to: 1) assess whether leopards were utilizing vegetation types at random (6668 leopard GPS locations were used to determine frequency of occurrence in each vegetation type), 2) whether leopards were hunting equally in each vegetation type, and 3) whether leopards were showing preference for particular prey. Only habitat and prey that fell within each collared leopard's home range ( $95 \%$ minimum convex polygon) was considered 'available', resulting in expected proportions of 'available' and 'used' habitat types and prey species derived from prey density and biomass estimates (see above). For example, to determine how many female leopard GPS locations should be located in GR habitat if this habitat is used randomly, we used the equation:

\section{Expected use $=$ total number of GPS locations $\times$ (area of available GR habitat/total area of all habitats available) $\times 100) \%$}

Resulting in $n=220$ GPS locations (i.e. expected use) for GR habitat, where only $n=68$ GPS locations were actually recorded. We used a Wilcoxon rank sum test with Yate's continuity correction to evaluate the difference between the average weight of cached and non-cached prey species. All tests were considered statistically significant at $\alpha \leq 0.05$. Analyses were conducted with R v.2.13.0 using preloaded packages ( $\mathrm{R}$ Development Core Team 2011). 
Table 1. Total population estimates (animals $/ \mathrm{km}^{2}$ ) of 17 leopard (Panthera pardus) prey species by vegetation type from Welgevonden Private Game Reserve, Limpopo Province, South Africa, for 2010.

\begin{tabular}{|c|c|c|c|c|c|c|c|c|}
\hline \multirow[b]{2}{*}{ Species } & \multicolumn{6}{|c|}{ Vegetation types* } & \multirow{2}{*}{$\begin{array}{c}\text { Total population } \\
\text { size }\end{array}$} & \multirow{2}{*}{$\begin{array}{l}\text { Correction factor } \\
\text { (Owen-Smith } \\
\text { \& Mills 2008) }\end{array}$} \\
\hline & GR & ORW & MCW & MW & OW & TOW & & \\
\hline Chacma baboon & 0.98 & 2.28 & 2.15 & 1.58 & 2.80 & 4.17 & 756 & 1.2 \\
\hline Blue wildebeest & 8.16 & 1.98 & 0.93 & 0.40 & 8.20 & 3.24 & 668 & 1.2 \\
\hline Burchell's zebra & 3.29 & 1.70 & 1.79 & 0.97 & 5.29 & 2.64 & 688 & 1.2 \\
\hline Bushbuck & 0.10 & 0.02 & 0.01 & 0.01 & 0.00 & 0.25 & 12 & 3 \\
\hline Bushpig & 0.12 & 0.02 & 0.09 & 0.10 & 0.00 & 0.21 & 30 & 3 \\
\hline Common duiker & 0.84 & 0.26 & 0.21 & 0.96 & 0.23 & 0 & 102 & 1 \\
\hline Common reedbuck & 5.22 & 2.63 & 0.04 & 0.41 & 0.00 & 0.89 & 279 & 3 \\
\hline Eland & 1.30 & 0.98 & 0.56 & 0.84 & 0.98 & 0.34 & 234 & 1.5 \\
\hline Impala & 11.87 & 3.22 & 1.48 & 2.33 & 7.44 & 12.75 & 1192 & 1.7 \\
\hline Klipspringer & 0.19 & 0.19 & 0.77 & 1.5 & 0.3 & 0.95 & 239 & 1 \\
\hline Kudu & 0.35 & 0.73 & 0.79 & 1.01 & 0.94 & 3.13 & 322 & 1.8 \\
\hline Mountain reedbuck & 0.20 & 0.11 & 0.07 & 0.80 & 0.00 & 0.29 & 51 & 3 \\
\hline Red hartebeest & 3.03 & 0.70 & 0.08 & 0.87 & 0.31 & 0.27 & 150 & 1.2 \\
\hline Steenbok & 0.17 & 0.09 & 0.00 & 0.03 & 0.03 & 0.01 & 10 & 2 \\
\hline Tsessebe & 0.08 & 0.03 & 0.00 & 0.01 & 0.02 & 0.02 & 5 & 1.7 \\
\hline Warthog & 8.68 & 0.96 & 0.38 & 0.94 & 2.09 & 2.72 & 435 & 2.5 \\
\hline Waterbuck & 2.53 & 0.28 & 0.26 & 1.32 & 0.85 & 1.87 & 214 & 1.7 \\
\hline
\end{tabular}

*See Fig. 1 for vegetation type codes.

\section{RESULTS}

A total of 31244 direct observations of prey species were recorded during aerial counts, comprising 17 species (Table 1). Grasslands were the most densely populated habitat and contained the highest prey biomass estimates. Mixed closed woodland was the most densely vegetated habitat and tall open woodland contained the highest vegetative biomass estimates (Table 2). Female leopards used mixed closed woodland and tall open woodland significantly more than expected, mixed woodland in accordance with availability and avoided grasslands, open rocky woodland, and open woodland $\left(G_{5}=595.9, P<0.001\right)$.

Most clusters ( $n=227 ; 63 \%$ ) did not have kills associated with them, and may therefore have been resting sites, mating sites or areas frequented by female leopards for an unknown resource (e.g. scent-marking sites, patrolling routes; Pitman, et al. 2012). Kills ( $n=129)$ were located and identified (six kills were unidentifiable) between August 2010 and March 2011 (Table 3). Average prey weight (median $=12.5 \mathrm{~kg}$ ) was at the lower end of a leopard's preferred prey weight range (Hayward et al. 2006). Certain species were predated upon more than others $\left(G_{8}=109.4, P<0.001\right)$. Leopards killed common duiker, klipspringer and mountain reedbuck (Redunca fulvorufula) more than expected, chacma baboon (Papio ursinus) and impala (Aepyceros melampus) in accordance with

Table 2. Mean prey density, prey biomass, woody vegetation density, and vegetative biomass by vegetation type from Welgevonden Private Game Reserve, Limpopo Province, South Africa, for 2010.

\begin{tabular}{lrrrrrr}
\hline & \multicolumn{5}{c}{ Vegetation types* } \\
\cline { 2 - 7 } & \multicolumn{1}{c}{ GR } & ORW & MCW & MW & OW & TOW \\
\hline Total prey density $\left(\right.$ animals $\left./ \mathrm{km}^{2}\right)$ & 47.12 & 16.17 & 9.61 & 14.08 & 29.49 & 33.75 \\
Prey biomass $\left(\mathrm{kg} / \mathrm{km}^{2}\right)$ & 1744 & 574 & 355 & 506 & 1143 & 1226 \\
Woody vegetation density & 11904 & 45555 & 126458 & 116111 & 55557 & 95758 \\
(woody stems $\left./ \mathrm{km}^{2}\right)$ & 1161801 & 298168 & 1129009 & 481161 & 1083833 & 4813323 \\
Vegetative biomass $\left(\mathrm{kg} / \mathrm{km}^{2}\right)$ & & & & & & \\
\hline
\end{tabular}

*See Fig. 1 for vegetation type codes. 
Table 3. Number of female leopard (Panthera pardus) kills of 18 prey species located using contextual GPS cluster analysis (Pitman et al. 2012) by vegetation type from Welgevonden Private Game Reserve, Limpopo Province, South Africa, during August 2010 - March 2011.

\begin{tabular}{|c|c|c|c|c|c|c|c|}
\hline \multirow[b]{2}{*}{ Species } & \multicolumn{7}{|c|}{ Number of kills in each vegetation type* } \\
\hline & Kills & GR & ORW & MCW & MW & OW & TOW \\
\hline African civet & 2 & 0 & 0 & 1 & 0 & 0 & 1 \\
\hline Chacma baboon & 18 & 0 & 0 & 15 & 0 & 0 & 3 \\
\hline Banded mongoose & 5 & 0 & 0 & 5 & 0 & 0 & 0 \\
\hline Blue wildebeest & 5 & 0 & 0 & 2 & 0 & 0 & 3 \\
\hline Burchell's zebra & 10 & 0 & 1 & 9 & 0 & 0 & 0 \\
\hline Bushpig & 1 & 0 & 0 & 0 & 0 & 0 & 1 \\
\hline Common duiker** & 7 & 0 & 0 & 3 & 0 & 0 & 0 \\
\hline Common reedbuck & 1 & 0 & 0 & 1 & 0 & 0 & 0 \\
\hline Impala & 23 & 0 & 0 & 18 & 1 & 2 & 2 \\
\hline Jameson's red rock rabbit & 8 & 0 & 0 & 8 & 0 & 0 & 0 \\
\hline Klipspringer & 19 & 0 & 0 & 15 & 0 & 0 & 4 \\
\hline Kudu & 4 & 0 & 0 & 4 & 0 & 0 & 0 \\
\hline Leopard tortoise & 1 & 0 & 0 & 1 & 0 & 0 & 0 \\
\hline Mountain reedbuck & 12 & 0 & 0 & 12 & 0 & 0 & 0 \\
\hline Rock hyrax & 1 & 0 & 0 & 1 & 0 & 0 & 0 \\
\hline Vlei rat & 1 & 0 & 0 & 1 & 0 & 0 & 0 \\
\hline Warthog & 1 & 0 & 0 & 1 & 0 & 0 & 0 \\
\hline Bird spp. & 4 & 0 & 0 & 2 & 0 & 0 & 2 \\
\hline Unknown & 6 & 0 & 0 & 5 & 0 & 0 & 1 \\
\hline Total kills & 125 & 0 & 1 & 104 & 1 & 2 & 17 \\
\hline
\end{tabular}

*See Fig. 1 for vegetation type codes.

${ }^{* \star}$ Four common duiker kills were located in areas outside Welgevonden for which habitat maps were not available.

availability, and avoided eland (Tragelaphus oryx), red hartebeest (Alcelaphus buselaphus), kudu (Tragelaphus strepsiceros), common reedbuck (Redunca arundinum), warthog (Phacochoerus africanus), bushpig Potamochoerus larvatus), waterbuck (Kobus ellipsiprymnus), blue wildebeest (Connochaetes taurinus) and zebra (Equus quagga).

Female leopards preferred to hunt in mixed closed woodland and tall open woodland, making $96 \%$ of kills in these two habitats, and avoided all other habitats when hunting $\left(G_{5}=19.1, P=0.001\right)$. Thirty-one kills (24\%) were cached in trees, these prey were significantly heavier $(z=-2.1, P<0.05$; median $=31 \mathrm{~kg}$ ) than non-cached prey (median = $12 \mathrm{~kg}$ ). No kills were concealed with vegetation.

Most kills (53\%) occurred during diurnal hours, peaking at mid-to-late afternoon, followed by nocturnal $(25 \%)$ and crepuscular $(22 \%)$ hours (Table 4). Female leopards were most active during daylight hours (Fig. 2).

\section{DISCUSSION}

Female leopards on Welgevonden did not use or hunt in habitats with the greatest abundance of prey. Leopards require not only high numbers of prey to hunt, but rather the appropriate ecological factors like vegetation cover, to ensure hunts are successful (Balme et al. 2007). On Welgevonden, female leopards may be exploiting high levels of vegetation cover (e.g. mixed closed woodland; greatest vegetation density) by using it to prevent detection during hunting, thereby increasing the probability of capturing prey (Hayward et al. 2006). Although mixed closed woodland contains the least number of prey species, this 'predator detection versus prey abundance' trade-off makes hunting in this habitat highly profitable and worthwhile for leopards $-83 \%$ of kills occurred here. It is plausible that these factors enabled leopards to successfully hunt species that are normally regarded as challenging or high-risk prey like chacma baboons (Cowlishaw 1994; Jooste et al. 2013), as most ( $n=15 ; 83 \%)$ were killed in this habitat. The use of tall open woodland for hunting may be a result of some key factors that have been shown to facilitate successful leopard hunts: the abundance of prey (33.75 animals $/ \mathrm{km}^{2}$; Table 2), suitable vegetation cover (i.e. greatest vegetation biomass; Balme et al. 2007), and the abundance 


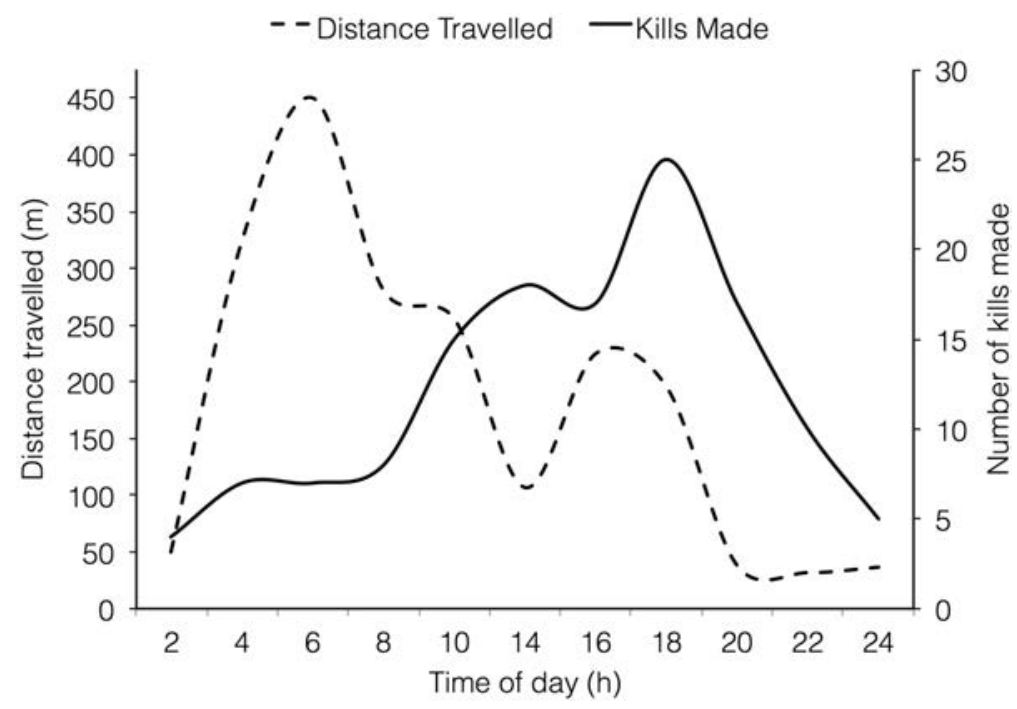

Fig. 2. The average distance travelled $(\mathrm{m})$ and number of kills made by three female leopards (Panthera pardus) compared over a $24 \mathrm{~h}$ cycle from Welgevonden Private Game Reserve, Limpopo Province, South Africa, during August 2010 - March 2011. Note: midday data were not collected due to a GPS programming error.

of refuge trees - large wild seringa and Transvaal beech trees dominate this habitat (Pitman et al. 2012).

Leopards in our study selected certain prey species over others. This selection may not only be a result of dietary preference (Hayward et al. 2006), but rather the pursuit of certain prey in accordance with energy expenditure (Krebs \& Davies 1993). Predation on kudu fits this hypothesis: leopards are reported to target and kill kudu in the Waterberg (Swanepoel 2009). However, the likelihood of capturing prey such as impala and klipspringer provide leopards with an easier, less risky option (Hayward et al.2006). Kudu were most abundant in tall open woodland - a habitat frequently used by leopards - yet no kudu kills occurred here. Kudu are a tall, hyper-vigilant species (Périquet et al. 2010) that may be able to detect a hunting leopard in this habitat where environmental features like vegetation density and/or vegetation structure may be below a threshold that enables successful capture (Balme et al. 2007). In contrast, impala were least abundant in mixed closed woodland, yet most ( $n=18 ; 78 \%$ ) impala kills occurred here, suggesting this dense habitat offers leopards easier predatory opportunities possibly due to the presence of thick vegetation that permits a stealthier hunting approach.

Leopards are known to take refuge in rugged habitats when potential threats by superior competitors exist (Sunquist \& Sunquist 2002), and then enter lower lying, prey abundant habitats to forage (Hayward et al. 2006). We hypothesize that the competitive pressure exerted by lions - which

Table 4. Number of female leopard (Panthera pardus) kills of 18 prey species by time of day (three phases) from Welgevonden Private Game Reserve, Limpopo Province, South Africa, during August 2010 - March 2011.

\begin{tabular}{|c|c|c|c|}
\hline \multirow[b]{2}{*}{ Species } & \multicolumn{3}{|c|}{ Number of kills } \\
\hline & Crepuscular & Diurnal & Nocturnal \\
\hline African civet & 0 & 1 & 1 \\
\hline Chacma baboon & 2 & 13 & 3 \\
\hline Banded mongoose & 2 & 3 & 0 \\
\hline Blue wildebeest & 2 & 2 & 1 \\
\hline Burchell's zebra & 2 & 6 & 2 \\
\hline Bushpig & 0 & 0 & 1 \\
\hline Common duiker & 2 & 4 & 1 \\
\hline Common reedbuck & 0 & 0 & 1 \\
\hline Impala & 5 & 11 & 7 \\
\hline $\begin{array}{l}\text { Jameson's red rock } \\
\text { rabbit }\end{array}$ & 2 & 5 & 1 \\
\hline Klipspringer & 5 & 8 & 6 \\
\hline Kudu & 2 & 2 & 0 \\
\hline Leopard tortoise & 0 & 0 & 1 \\
\hline Mountain reedbuck & 1 & 8 & 3 \\
\hline Rock hyrax & 0 & 0 & 1 \\
\hline Vlei rat & 1 & 0 & 0 \\
\hline Warthog & 0 & 1 & 0 \\
\hline Bird spp. & 1 & 2 & 1 \\
\hline Unknown & 2 & 2 & 2 \\
\hline Total & 29 & 68 & 32 \\
\hline
\end{tabular}


dominate these lower lying, open habitats (Kilian 2003) - force leopards to use rugged areas at greater frequencies that would normally exist, thus increasing the contact rates leopards have with species common to this environment, such as klipspringer and mountain reedbuck (Norton 1997a,b). This could explain why female leopards selected mountain reedbuck and klipspringer more than expected on Welgevonden whereas in other regions these species are not normally favoured (Hayward et al. 2006). Feeding sites were often located in rugged terrain (Pitman et al. 2012), which may be a direct result of our hypothesized inter-specific avoidance behaviour (i.e. leopards feel safer feeding here, where lions infrequently venture).

Other potential leopard prey species like common reedbuck, waterbuck, red hartebeest, blue wildebeest and zebra were avoided for two possible reasons: 1) these species are predominantly open habitat specialists and have lower encounter rates with leopards on Welgevonden, and 2) these species could inflict serious injury on leopards (Hayward et al. 2006). Nevertheless, given that aerial count data can misrepresent prey abundance, even after correction factors have been applied, it would be wise to interpret our prey preference results with caution. Though we are confident that twelve years of aerial counts provide a good representation of prey distribution, prey abundance within each vegetation type would have benefited from additional census techniques such as roadstrip counts (Hirst 1969).

Predators are vulnerable during feeding and leopards are reported to climb trees not only to rest, but to avoid conflict with competitors (Bailey 2005). The high frequencies of refuge trees at kill sites on Welgevonden demonstrate the importance of ecological features like trees for leopard foraging and survival (Pitman et al. 2012). Caching of kills in trees on Welgevonden was fairly common $(23 \%)$. This behaviour is thought to be a result of the competitive pressure exerted by scavengers (Balme et al.2007). However, cached prey species were significantly heavier (mean $=68 \mathrm{~kg}$ ) than non-cached prey species (mean $=33 \mathrm{~kg}$ ), and may therefore be a response to an excess of food following satiation (Swanepoel 2009). Female leopards did not cover prey with vegetation as is so often seen in other studies (Grimbeek 1992; Karanth \& Sunquist 2000). The high density and olfactory capabilities of scavengers on Welgevonden, particularly from brown hyaena (Hyaena brunnea) (Wiesel 2006), may suggest this hiding behaviour is ineffective.

Leopards are usually nocturnally active in savanna ecosystems (Bailey 2005), and mostly diurnal in forest ecosystems (Jenny \& Zuberbühler 2005). In the Waterberg, leopards are predominantly nocturnal (L.H. Swanepoel, unpubl, data, 2012). On Welgevonden, female leopards were primarily active during the day and least active between 20:00 and 02:00 (Fig. 2). The reason for this decrease in activity during these nocturnal hours is unclear but may be a result of feeding activity (i.e. digestion) and/or intraspecific avoidance.

Although these findings suggest that leopards are adaptable, they are still governed to some extent by interactions with their environment, their prey, their competitors and people. In this mountainous landscape, female leopards demonstrate clear habitat preference. Their choice of hunting and refuge grounds are not determined simply by the availability of habitat, but rather by complex and subtle ecological dynamics. We suggest that these leopards are selecting habitats that balance energy expenditure against the likelihood of capturing prey in an attempt to maximize efficiency (Balme et al. 2007), whilst reducing inter-specific competition, which limits their foraging ability and affects their choice of prey (Creel et al. 2001). On Welgevonden, female leopards are not entirely opportunistic, nor generalist, but rather highly adapted to the pressures exerted upon them from within (ecological factors, inter-specific competition, human disturbance) and outside (persecution) the reserve.

Leopard predation is greatly affected by environmental factors (e.g. vegetation cover; Balme et al. 2007) and anthropogenic pressure (e.g. bush meat hunting in the Congo Basin; Henschel et al. 2011) which influence the suitability of available habitats and raise further questions regarding leopard population densities in other regions. Considerations need to be made that account for inter-specific interactions, habitat refugia, the likelihood of capturing prey, vegetation density and human disturbance when delineating suitable habitats and corridors for leopard conservation. These issues highlight our limited knowledge of leopard ecological requirements, and challenge our perceptions regarding the suitability of habitats.

\section{ACKNOWLEDGEMENTS}

This research was funded by the Wilson Foundation and the Centre for Wildlife Management. 
L.H.S. was supported by a NRF grant (No. 74819). Darien Simpson and Anton van Loggerenberg assisted in the capture of leopards. Thanks to Esmarie Jooste for her assistance in data collection and processing. We thank staff at Welgevonden who assisted on numerous occasions during the fieldwork, in particular, Andrè Burger, Gerhardt Lorist and Shaun McCartney.

\section{REFERENCES}

ATHREYA, V., ODDEN, M., LINNELL, J.D. \& KARANTH, K.U. 2011. Translocation as a tool for mitigating conflict with leopards in human-dominated landscapes of India. Conserv Biol. 25: 133-141.

BAILEY, T. N. 2005 The African leopard: ecology and behavior of a solitary felid, 2nd edn. The Blackburn Press, New Jersey.

BALME, G.A., HUNTER, L.T.B. \& SLOTOW, R. 2007. Feeding habitat selection by hunting leopards Panthera pardus in a woodland savanna: prey catchability versus abundance. Anim. Behav. 74: 589-598.

BEYER, H.L., 2004 Hawth's analysis tools for ArcGIS.

BUYS, D. \& KEOGH, H.J. 1984 Notes on the microstructure of hair of the Orycteropodidae, Elephantidae, Equidae, Suidae and Giraffidae. S. Afr. J. Wildl. Res. 14: 111-119.

COWLISHAW, G. 1994. Vulnerability to predation in baboon populations. Behaviour. 131:293-304.

CREEL, S., SPONG, G. \& CREEL, N.M., 2001. Interspecific competition and population biology of extinction-prone carnivores. In: Conservation of carnivores (pp. 35-60). Cambridge University Press, Cambridge.

DOUGLAS, R. M. 1989. A new method of crosssectioning hair of larger mammals. S. Afr. J. Wildl. Res. 19: 73-76.

DREYER, J.H. 1966. A study of hair morphology in the family bovidae. Onderstepoort J. Vet. Res. 33: 379-472.

FRANK, L., SIMPSON, D. \& WOODROFFE, R. 2003. Foot snares: an effective method for capturing African lions. Wildl. Soc. Bull. 31: 309-314.

GRIMBEEK, A.M., 1992. The ecology of the leopard Panthera pardus in theWaterberg. M.Sc. dissertation, University of Pretoria. Pretoria, South Africa.

HARIHAR, A., PANDAV, B. \& GOYAL, S.P. 2011. Responses of leopard Panthera pardus to the recovery of a tiger Panthera tigris population. J. Appl. Ecol. 48: 806-814.

HAYWARD, M., O'BRIEN, J. \& KERLEY, G. 2007. Carrying capacity of large African predators: predictions and tests. Biol. Conserv. 139: 219-229.

HAYWARD, M. W., HENSCHEL, P., O'BRIEN, J., HOFMEYR, M., BALME, G. \& KERLEY, G. I. H. 2006. Prey preferences of the leopard (Panthera pardus). J. Zool. 270: 298-313.

HENSCHEL, P., HUNTER, L.T.B., COAD, L., ABERNETHY, K.A. \& MÜHLENBERG, M. 2011. Leopard prey choice in the Congo Basin rainforest suggests exploitative competition with human bushmeat hunters. J. Zool. 285: 1-10.

HIRST, S.M. 1969. Road-strip census techniques for wild ungulates in African woodland. J. Wildl. Manage. 33: 40-48.

JENNY, D. \& ZUBERBÜHLER, K. 2005. Hunting behaviour in West African forest leopards. Afr. J. Ecol. 43 : 197-200.

JOOSTE, E., PITMAN, R.T., VAN HOVEN, W. \& SWANEPOEL, L.H. 2013. Unusually high predation on chacma baboons (Papio ursinus) by female leopards (Panthera pardus) in the Waterberg Mountains, South Africa. Folia Primatol. 83: 353-360.

KARANTH, K.U. \& SUNQUIST, M.E. 2000. Behavioural correlates of predation by tiger Panthera tigris, leopard Panthera pardus and dhole Cuon alpinus in Nagarahole, India. J. Zool. 250: 255-265.

KEOGH, H.J., 1979. An atlas of hair from southern African mammal species with reference to its taxonomic and ecological significance. Ph.D. thesis, University of Pretoria, Pretoria, South Africa.

KEOGH, H.J. 1983. A photographic reference system of the microstructure of the hair of southern African bovids. S. Afr. J. Wildl. Res. 13: 89-132.

KILIAN, P.J., 2003. The ecology of reintroduced lions on the Welgevonden Private Game Reserve, Waterberg. M.Sc. dissertation, University of Pretoria, Pretoria, South Africa.

KREBS, J.R. \& DAVIES, N.B. 1993. An introduction to behavioural ecology. Blackwell Scientific, Oxford.

MARKER, L.L. \& DICKMAN, A.J. 2005. Factors affecting leopard (Panthera pardus) spatial ecology, with particular reference to Namibian farmlands. S. Afr. J. Wildl. Res. 35: 105-115.

MUCINA, L. \& RUTHERFORD, M.C. 2006. The vegetation of South Africa, Lesotho and Swaziland. Sterlitzia 19. South African National Biodiversity Institute, Pretoria.

NORTON, P., 1997a. Klipspringer Oreotragus oreotragus. In: The complete book of African mammals (p. 264). Struik, Cape Town.

NORTON, P., 1997b. Mountain reeduck Redunca fulvorufula. In: The complete book of African mammals (p. 289). Struik, Cape Town.

OWEN-SMITH, N. \& MILLS, M.G.L. 2008. Predator-prey size relationships in an African large-mammal food web. J. Anim. Ecol. 77: 173-183.

PACKER, C., BRINK, H., KISSUI, B.M., MALITI, H., KUSHNIR, H. \& CARO, T. 2011. Effects of trophy hunting on lion and leopard populations in Tanzania. Conserv. Biol. 25: 142-153.

PARKER, A., 2004. The vegetation ecology of Welgevonden private nature reserve. M.Sc. dissertation, University of the Witswatersrand, Johannesburg, South Africa.

PÉRIQUET, S., VALEIX, M., LOVERIDGE, A.J., MADZIKANDA, H., MACDONALD, D.W. \& FRITZ, H. 2010. Individual vigilance of African herbivores while drinking: the role of immediate predation risk and context. Anim. Behav. 79: 665-671.

PITMAN, R.T., SWANEPOEL, L.H. \& RAMSAY, P. 2012 Predictive modelling of leopard predation using contextual Global Positioning System cluster analysis. J. Zool. 288: 222-230.

R DEVELOPMENT CORE TEAM. 2011. R: a language and environment for statistical computing. R Foundation for Statistical Computing, Vienna, Austria. 
RAY, J.C., HUNTER, L. \& ZIGOURIS, J. 2005. Setting conservation and research priorities for large African carnivores. Wildlife Conservation Society, New York.

SKINNER, J.D. \& CHIMIMBA, C.T. 2005. The mammals of the South African sub-region. Struik Publishers, Cape Town, South Africa.

STANDER, P.E., HADEN, P.J., KAQECE \& GHAU 1997. The ecology of asociality in Namibian leopards. J. Zool. 242: 343-364.

STEINMETZ, R., SEUATURIEN, N. \& CHUTIPONG, W. 2013. Tigers, leopards, and dholes in a half-empty forest: assessing species interactions in a guild of threatened carnivores. Biol. Conserv. 163: 68-78.

STUART, C.T. \& STUART, T. 2000. Field guide to the larger mammals of Africa. Struik Publishers, Cape Town, South Africa.
SUNQUIST, M.E. \& SUNQUIST, F. 2002. Wild cats of the world. University of Chicago Press, London, U.K.

SWANEPOEL, L.H., 2009. Ecology and conservation of leopards Panthera pardus on selected game ranches in the Waterberg region, Limpopo, South Africa. Centre of Wildlife Management. M.Sc. dissertation, University of Pretoria, Pretoria, South Africa.

TAMBLING, C.J., CAMERON, E.Z., DU TOIT, J.T. \& GETZ, W.M. 2010. Methods for locating African lion kills using global positioning system movement data. J. Wildl. Manage. 74: 549-556.

WIESEL, I. 2006. Predatory and foraging behaviour of brown hyenas (Parahyaena brunnea (Thunberg, 1820)) at Cape fur seal (Arctocephalus pusillus pusillus (Schreber, 1776)) colonies. Ph.D. thesis, University of Hamburg, Hamburg, Germany.

Corresponding Editor: M.W. Hayward 